\title{
A STUDY ON EXPERIMENTAL INVESTIGATION USING CEMENT CONCRETE WITH VARIYING PERCENTAGE OF RICE HUSK ASH
}

\author{
Dr.P.Valli and Dr.P.R.Dhevasenaa \\ e-mail: valli_au@yahoo.in, and senaadheva@gmail.com, \\ Assistant Professor, \\ Department of Civil Engineering, Government College of Engineering, Srirangam, Trichy-12. \\ Tamilnadu, India.
}

\begin{abstract}
The concrete industries introduce various related techniques to integrate and utilize a waste material, which are easily acceptable, easily available, and economically within the buying powers of an ordinary people. Presence of such materials in cement concrete not only reduces the carbon dioxide emission, but also impact significant improvement in workability and durability. For control of concrete strength, IS method of mix proportion is used and considering this as basis, mix design for replacement method has been made. In the present study five different replacement levels namely $10 \%, 20 \%$, and $30 \%$ of RHA are chosen. Large range of curing periods starting from 7 days, 14days, and 28days are considered in the present study.
\end{abstract}

KEY WORDS: Rice Husk ash, Concrete, Quarry Dust

\section{INTRODUCTION}

To improve the properties of concrete there are various experimental study available, whether it is a natural materials or recycled materials or blend of two synthetic materials in the concrete mix. If the waste cannot be disposed properly it will lead to social and environmental problem. The high cost of conventional building materials is a major factor affecting building construction. This has necessitated research into alternative materials of construction. Rice husk ash are generally used as landfills. To avoid this many reuse methods for rice husk ash are carried according to the need. With global economic recession coupled with market inflationary trends, constituent materials used for building structures have led to a very high cost of construction. Hence materials \& engineering scientists are committed to use local materials to replace costly conventional materials partially or fully. Numerous researchers have been carried out in this regard to sustainability reduce in the cost and ability to produce high density concrete are added advantage of such materials.

The new concrete aggregates typically account about $75 \%$ of the concrete volume and play a substantial role in different concrete properties such as workability, strength, dimension stability and durability. There is a growing interest in using waste materials as alternative aggregate materials and significant research is made on the use of many different materials as cement replacement such as fly ash, bagasse ash and 
timber ash. This kind of waste material can solve problems of lack of concrete in many construction sites and reduce environmental problems related to aggregate mining and waste disposal.

\section{SCOPE}

- Use of rice husk ash as an environment friendly alternative than to dumping it as waste.

- Reduce the composition of natural resources used in concrete.

- Reduce environmental pollution.

- Economical.

\section{OBJECTIVES}

- To improve the strength of the concrete

- To evaluate the utility of rice husk ash as a replacement in cement concrete with varying percentage.

- To investigate the physical and chemical properties of rice husk ash used concrete.

- To compare the properties of rice husk with cement.

- To compare the rice husk ash concrete mix with conventional concrete mix.

- To determine the compressive strength, split tensile strength and workability of concrete with cement replaced by rice husk ash.

- To evaluate the increase strength of Rice husk ash replaced concrete in comparison with the conventional concrete.

\section{NEED FOR PRESENT SYUDY}

- To find a better alternative way to the supplementary cementitiious material.

- From the supplementary replacement, reduce the usage of cement content.

- Cement industries emits more amount of toxic co2, which leads to environmental issues. Through this supplementary replacement we intend reduce cement production and pollution.

- To provide a high-performance concrete than the conventional concrete.

- Making concrete using waste material saves energy and converse primary resources. The more material reused; the fewer resource was consumed which leads to safe sustainable environment.

\section{METHODOLOGY}

- Material collection

- Preliminary test of materials

- Mix design

- Sample preparation

- Testing

- Result and discussion

\section{MATERIALS}

- Cement.

- Rice husk ash (RHA).

- Fine aggregate.

- Coarse aggregate.

- Water.

\section{RICE HUSK ASH (RHA)}

Rice Husk Ash is the ash that is obtained by burning the rice husk until it gets reduced by $25 \%$. The rice husk ash contain more amount of silica , and it is highly pozzolonic material. The ash is $90-95 \%$ of silica ( $\mathrm{SiO} 2)$, light weight, with very high external surface area. 


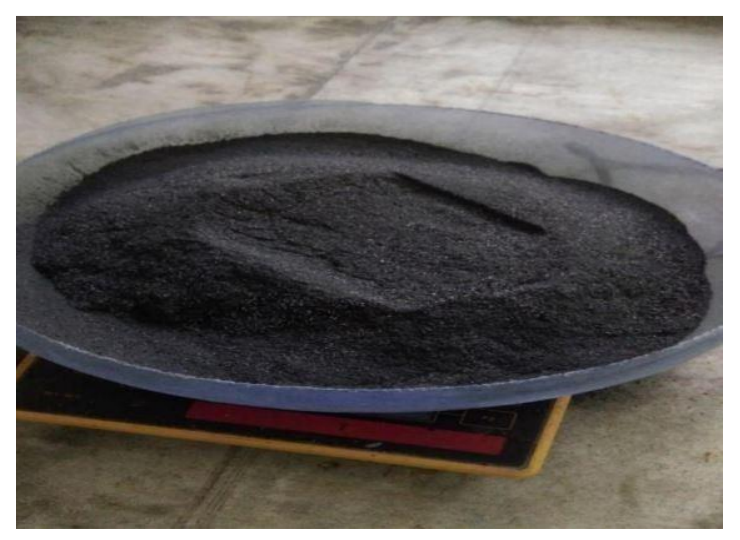

\section{QUARRY DUST}

Quarry dust is a waste which was obtained as a by-product during the production of aggregates through the crushing process of rocks in rubble crushing units. It is used as a replacement of sand quarry dust which is passing through IS $4.75 \mathrm{~mm}$ sieve and retained on 150 micron sieve is considered for the experimental investigation.

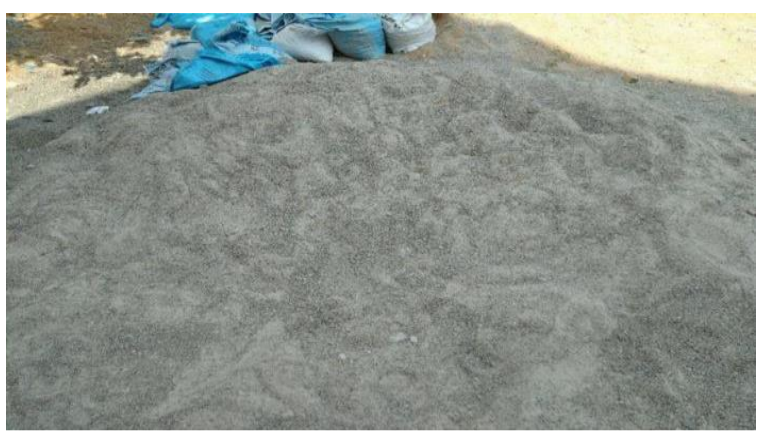

\begin{tabular}{|l|l|}
\hline Property & \\
\hline Colour & Grey with slight black \\
\hline Bulk density & $104.9 \mathrm{~kg} / \mathrm{m} 3$ \\
\hline Specific gravity & 1.96 \\
\hline fineness & $2775 \mathrm{~cm} 2 / \mathrm{gm}$ \\
\hline Avg particle size & $150.47 \mu \mathrm{m}$ \\
\hline
\end{tabular}

\begin{tabular}{|l|l|}
\hline $\begin{array}{l}\text { Physical properties of } \\
\text { quarry dust } \\
\text { Specific gravity }\end{array}$ & 2.96 \\
\hline Fineness modulus & 2.48 \\
\hline Water absorption & $1 \%$ \\
\hline $\begin{array}{l}\text { Physical properties of } \\
\text { cement }\end{array}$ & \\
Specific gravity & 3.13 \\
\hline Initial setting time & 29 mins \\
\hline Final setting time & 600 mins \\
\hline Physical properties of C.A & \\
Specific gravity & 3.15 \\
\hline Water absorption & $0.5 \%$ \\
\hline Impact value & $13.7 \%$ \\
\hline Crushing value & 25.4 \\
\hline
\end{tabular}

\begin{tabular}{|c|c|}
\hline Component & $\%$ \\
\hline Silica & 92.1 \\
\hline Alumina & 0.51 \\
\hline Iron oxide & 0.40 \\
\hline Calcium oxide & 0.55 \\
\hline Potassium oxide & 1.53 \\
\hline Titanium di oxide & 0.02 \\
\hline Manganese oxide & 0.08 \\
\hline $\begin{array}{l}\text { Phosphorous penta } \\
\text { oxide }\end{array}$ & 0.08 \\
\hline Sulphur tri oxide & 0.12 \\
\hline
\end{tabular}




\section{MIX PROPORTION OF CONCRETE}

\begin{tabular}{|l|l|l|l|l|l|}
\hline $\begin{array}{l}\text { \% Of } \\
\text { Replace } \\
\text { ment }\end{array}$ & Cement & $\begin{array}{l}\text { Water } \\
\text { (W/C= } \\
0.42)\end{array}$ & $\begin{array}{l}\text { Fine } \\
\text { Aggrega } \\
\text { te }\end{array}$ & $\begin{array}{l}\text { Coarse } \\
\text { Aggregate }\end{array}$ & $\begin{array}{l}\text { Rice } \\
\text { husk } \\
\text { Ash }\end{array}$ \\
\hline & \multicolumn{5}{|c|}{$\mathrm{Kg} / \mathrm{m} 3$} \\
\hline 10 & 398.58 & 186 & 725.11 & 1429.61 & 44.28 \\
\hline 20 & 354.3 & 186 & 725.11 & 1429.61 & 88.56 \\
\hline 30 & 310.02 & 186 & 725.11 & 1429.61 & 132.84 \\
\hline
\end{tabular}

\section{COMPRESSIVESTRENGTHTEST}

Compression test according to IS: 516(1959) is carried out on the cubes. The specimens are loaded at a constant strain rate until failure. The results of compressive strength of cubes for 7 days, 14 days and 28 days are as follows

Table 10.1Compression strength test result ( 7 days)

\begin{tabular}{|c|c|c|c|c|c|}
\hline S.No & 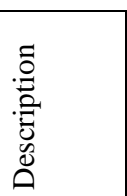 & 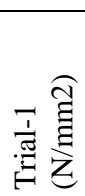 & 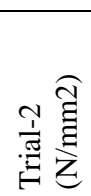 & 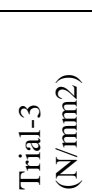 & 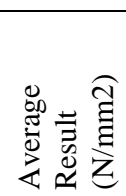 \\
\hline 1 & 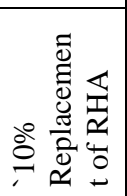 & 17.77 & 22.22 & 19.33 & 19.84 \\
\hline 2 & 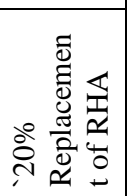 & 13.33 & 15.11 & 16.88 & 15.11 \\
\hline 3 & 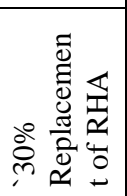 & 10.66 & 12.88 & 8.88 & 10.81 \\
\hline
\end{tabular}

Table 10.2 Compressive strength for conventional concrete

\begin{tabular}{|c|c|c|c|}
\hline 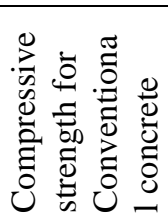 & $\begin{array}{l}7 \\
\text { Days }\end{array}$ & 14 Days & 28 Days \\
\hline & 22.1 & 30.6 & 33.66 \\
\hline
\end{tabular}

Table 10.3 Compression strength test result (14 days)

\begin{tabular}{|c|c|c|c|c|c|}
\hline S.No & 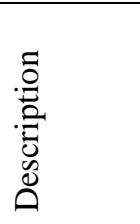 & 蔦 & 胥 & 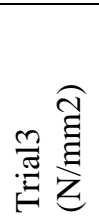 & 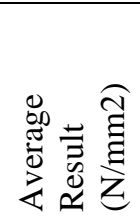 \\
\hline 1 & $\begin{array}{l}10 \% \\
\text { Replace } \\
\text { ment of } \\
\text { RHA }\end{array}$ & 28 & 23.11 & 25.33 & 25.48 \\
\hline 2 & $\begin{array}{l}20 \% \\
\text { Replace } \\
\text { ment of } \\
\text { RHA }\end{array}$ & $\begin{array}{l}21.7 \\
9\end{array}$ & 16.44 & 19.11 & 19.11 \\
\hline 3 & $\begin{array}{l}30 \% \\
\text { Replace } \\
\text { ment of } \\
\text { RHA }\end{array}$ & $\begin{array}{l}16.3 \\
3\end{array}$ & 15.11 & 13.33 & 14.92 \\
\hline
\end{tabular}


Table 10.4 Compression strength test result (28 days)

\begin{tabular}{|l|l|l|l|l|l|}
\hline $\begin{array}{l}\text { S.N } \\
\text { o }\end{array}$ & $\begin{array}{l}\text { Descrip } \\
\text { tion }\end{array}$ & $\begin{array}{l}\text { Trial 1 } \\
(\mathrm{N} / \mathrm{mm} 2)\end{array}$ & $\begin{array}{l}\text { Trial } \\
2 \\
(\mathrm{~N} / \mathrm{m} \\
\mathrm{m} 2)\end{array}$ & $\begin{array}{l}\text { Trial 3 } \\
(\mathrm{N} / \mathrm{m} \\
\mathrm{m} 2)\end{array}$ & $\begin{array}{l}\text { Avera } \\
\text { ge } \\
\text { Result } \\
(\mathrm{N} / \mathrm{m} \\
\mathrm{m} 2)\end{array}$ \\
\hline 1 & $\begin{array}{l}-10 \% \\
\text { Replace } \\
\text { ment of } \\
\text { RHA }\end{array}$ & 33.21 & 32.93 & 32.73 & 32.87 \\
\hline 2 & $\begin{array}{l}\text {-20\% } \\
\text { Replace } \\
\text { ment of } \\
\text { RHA }\end{array}$ & 29.21 & 28.26 & 29.71 & 27.48 \\
\hline 3 & $\begin{array}{l}30 \% \\
\text { Replace } \\
\text { ment of } \\
\text { RHA }\end{array}$ & 22.13 & 19.35 & 19.43 & 19.35 \\
\hline
\end{tabular}

\section{SPLIT TENSILE STRENGTH}

After 7 days, 14 days and 28 days curing of concrete cylinder, split tensile strength test carried on each concrete cylinder of each blend. Average of three split cylinder of each blend is calculated out and graph is plot.

Table 8.6 Split tensile strength result

\begin{tabular}{|c|c|c|c|}
\hline DAYS & 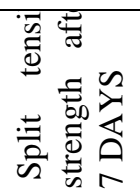 & 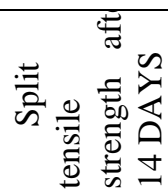 & 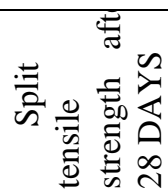 \\
\hline 空空。 & & $(\mathrm{N} / \mathrm{mm} 2)$ & \\
\hline 0 & 1.45 & 2.50 & 5.50 \\
\hline 10 & 1.32 & 2.40 & 5.21 \\
\hline 20 & 0.71 & 1.55 & 3.21 \\
\hline 30 & 0.25 & 0.56 & 1.82 \\
\hline
\end{tabular}

- It is found that the RHA concrete had significantly near compressive strength and split tensile strength compared to that of the conventional concrete.

- From the Experimental work it is found that the cement could be replaced with RHA upto maximum limit of $10 \%$. The optimum level of RHA content was achieved with $10 \%$ replacement.

- It is found that $10 \%$ replacement of cement by rice husk ash gives a maximum strength and high-quality factors than the conventional concrete.

- Thus, the environmental effects from the industrial waste can be significantly reduced and the cost of cement can be reduced by this RHA replacement.

- The use of rice husk ash as a replacement of cement in concrete is beneficial for better workability and strength as it imparts upto $30 \%$ of replacement level.

- Compared to the conventional concrete, replacement of rice husk ash in concrete decreases the use of cement from 20 to $30 \%$.

\section{CONCLUSIONS}


- The technical and economic advantages of incorporating Rice husk ash in concrete should be exploited by the construction and rice industries particularly rice growing nations like Asia countries.

\section{REFERENCES}

1. Ephraim et al., Compressive Strength of Concrete with RHA as partial replacement of ordinary Portland Cement, Scholarly Journal of Engineering Research(2012)1 p 32-36

2. A.Ramezanianpour.Bina.G ,Rahimi “" The role of rice husk ash in production of light weight structural panels", Proceeding 3rd International conference on concrete, May 2000 Teheran, Iran.

3. M. Nehdi, J. Duquette, A.EI Damatty, “ Performance of rice husk produced using a new technology as a mineral admixture in concrete", Cement and concrete Research(2003) PP.1203-1210

4. IS 10262:2009 (Reaffirmed 2004): Recommended guidelines for concrete mix design, Bureau of Indian Standards.

5. IS 456:2000 Plain and Reinforced Concrete - Code of Practice.

6. IS 455:1989 Portland slag cement specification fourth edition Bureau of Indian Standards, New Delhi.

7. IS 1199:1959 Determination of Workability Of Concrete.
8. IS516:1959 Methods for Testing For Strength of Concrete, Bureau of Indian Standards.

9. IS 383:1970 Standard Specifications for Testing of Construction Materials, Bureau of Indian Standards.

10. IS 5816:1999 Splitting Tensile Strength of Concrete - Method of Test. 